\section{International Scientific Journal Theoretical \& Applied Science}

p-ISSN: 2308-4944 (print) e-ISSN: 2409-0085 (online)

Year: $2014 \quad$ Issue: 12 Volume: 20

Published: $30.12 .2014 \quad \underline{\text { http://www.T-Science.org }}$
Natalija Anatolijevna Nestoruk candidate of pedagogical Sciences, senior lecturer,

Educational scientific professional-pedagogical Institute of the

Ukrainian engineering and pedagogical Academy natasha.nestoruk@yandex.ua

SECTION 21. The pedagogy. Psychology.

Innovations in education.

\title{
THE FORMATION OF THE RESEARCH COMPETENCE OF FUTURE SPECIALISTS
}

Abstract: The paper addresses the issue of improving the content of professional education. Investigated and substantiated the role of experimental research in the study of technical subjects, as a means of quality of formation of the research competence of future specialists.

Key words: competence, experimental studies, technical subjects, practical training, engineering experimentation.

Language: Ukrainian

Citation: Nestoruk NA (2014) THE FORMATION OF THE RESEARCH COMPETENCE OF FUTURE $\begin{array}{lllllll}\text { SPECIALISTS. ISJ Theoretical \& Applied } & \text { Science } 12 & \text { (20): } & 72-82 . & \text { doi: }\end{array}$ http://dx.doi.org/10.15863/TAS.2014.12.20.16

\section{ФОРМИРОВАНИЕ ИССЛЕДОВАТЕЛЬСКОЙ КОМПЕТЕНТНОСТИ БУДУЩИХ СПЕЦИАЛИСТОВ}

Аннотация: В работе рассматривается вопрос совершенствования содержания профессионального образования. Исследуется и обосновывается роль экспериментальных исследований при изучении технических дисииплин, как средства качественного формирования исследовательской компетентности будущчих специиалистов.

Ключевые слова: компетентность, экспериментальные исследования, технические дисииплины, практическая подготовка, инженерное экспериментирование.

\section{ФОРМУВАННЯ ДОСЛІДНИЦЬКОЇ КОМПЕТЕНТНОСТІ МАЙБУТНІХ ФАХІВЦІВ}

Анотація: B роботі розглядається питання удосконалення змісту професійної освіти. Досліджується та обтрунтовується роль експериментальних досліджень при вивченні технічних дисциплін, як засобів якісного формування дослідницької компетентності майбутніх фахівиів.

Ключові слова: компетентність, експериментальні дослідження, технічні дисципліни, практична підготовка, інженерне експериментування.

Постановка проблеми. Традиційно в педагогічній літературі експериментальні дослідження позиціонуються не як міждисциплінарна інтеграція практикоорієнтованої діяльності, що спрямовується на досягнення певної пізнавальної мети та набуття компетентностей, необхідних інженеру в майбутній професійній діяльності, а як вид навчальних робіт, передбачених змістом певної навчальної дисципліни. Але практика свідчить, що це стає на заваді якісній практичній підготовці майбутніх фахівців до інженерного експериментування, оскільки позасистемна діяльність не дозволяє студентам на належному рівні знайомитися 3 обладнанням i його можливостями, методами організації та технологіями проведення експериментальних досліджень, набувати технічного світогляду. У результаті ми спостерігаємо низку соціально значущих суперечностей між:

- зростаючими потребами суспільства у професійно компетентних інженерних кадрах, здатних вирішувати комплекс фахових завдань, i недостатнім рівнем їх професійної підготовки;

- необхідністю теоретичного обгрунтування процесу підготовки майбутніх інженерів- 
педагогів до проведення експериментальних досліджень у процесі вивчення технічних дисциплін і недостатнім вивченням зазначеної проблеми в педагогіці;

- потребами підготовки компетентних інженерів-педагогів електромеханічного профілю, здатних аналізувати, планувати, збирати схеми, налагоджувати устаткування, робити проби або ставити досліди, розраховувати, узагальнювати та складати висновки, й відсутністю відповідного науковообгрунтованого методичного забезпечення до проведення експериментальних досліджень при опануванні змістом технічних дисциплін.

Актуальність, виокремлені суперечності, соціально-педагогічне значення та недостатня розробленість порушеної проблеми, а також потреби освітньої практики зумовили вибір теми дослідження.

Аналіз останніх досліджень і публікацій. Проблеми якісної підготовки викладачів технічних дисциплін i шляхи їх вирішення відображені в працях О. Авраменка, С. Батишева, Н. Брюханової, Н. Ерганової, А. Касперського, О. Коваленко, М. Корця, М.Лазарєва, Н. Ничкало, Л. Сидорчук, В. Стешенка, Л. Тархан, О. Торубари, С. Яшанова та інших учених.

Формуванню професійних компетентностей і професіоналізму майбутніх фахівців у вищій школі набули актуальності в роботах Н. Бібік, О. Євсюкова, Е. Зеєра, А. Козибая, О. Коваленко,
М. Михнюк,
В. Петрук,
О. Пометун,

Н. Самойленко,

В. Стешенка,

Л. Тархан,

Л. Хоружої, В. Ягупова та ін.

Різні аспекти підготовки студентів технічних ВНЗ до інженерної експериментальної діяльності та безпосереднього включення елементів інженерного експериментування в навчальний процес вищих закладів освіти студіювалися С. Артюхом, А. Бояршиновою, Р. Горбатюком, В. Гріном, С. Іноземцевою, А. Касперським, М. Лазарєвим, М. Спіріним, В. Стешенком, О. Фішером та В. Лавровим і іншими дослідниками.

Але, як показав аналіз літератури, не зважаючи на наявність теоретичних, методологічних i педагогічних робіт, інформаційний розвиток освітнього простору, у змісті сучасних програм підготовки, наприклад, інженерів-педагогів електромеханічного профілю, належної уваги до інженерних досліджень і осучаснення методики їх проведення приділялося недостатньо.

Метою статті $\epsilon$ встановити та довести, що експериментальні дослідження при вивченні технічних дисциплін формують у майбутніх фахівців якісний компетентнісний комплекс, достатній для професійної діяльності в умовах реального виробничого або навчального процесу.
Виклад основного матеріалу. В освітньопрофесійних програмах підготовки фахівців за електромеханічними напрямами і відповідними спеціальностями інженерного (електромеханічного) та інженерно-педагогічного профілю «... вивчення технічних дисциплін $\epsilon$ системоутворюючим фактором усіх граней професійної підготовки майбутніх інженерів .... [I тому] ... для організації якісної професійної підготовки майбутнього фахівця треба відштовхуватися як від теорії до практики, так і від практики до теорії. Це означає, що лише через об'єктно-орієнтований підхід інтеграції технічних дисциплін інженерна підготовка стане засобом підготовки студентів до майбутньої професійної діяльності» [3, с. 171] - авторську стилістику збережено.

Інтеграція частіше за все витлумачується як поєднання у єдине ціле окремих частин або елементів системи шляхом взаємозближення й утворення взаємозв'язків між ними. На думку Ю. Ю. Бєлової, «інтеграція виступає складним міждисциплінарним науковим поняттям, сутність якого - якісне перетворення усередині кожного елементу, який належить системі» [3, с. 171]. Однак у більш загальному тлумаченні, інтеграція може мислитися й на ідейному та діяльнісному рівнях, що має на меті досягнення ідейної єдності змісту та діяльнісної універсальності навчальних дисциплін.

Інтерпретація функціонально-змістової сутності поняття інтеграції у такому контексті спричиняє переосмислення поняття цілісності а проекції на процес навчання й освіту взагалі. С. У. Гончаренко майже 20 років тому звертав увагу на те, що «традиційна предметна система навчання, яка складалася під впливом механістичної картини світу, відображає застарілу фрагментарну структуру знань. Сучасна наука все більше формується як цілісна система, структурно впорядкована за проблемним, а не лише предметним принципом» [5, с. 2], тому інтегративні процеси в освіті мають виходити на рівень ідейної єдності змісту в межах сукупностей фахово орієнтованих дисциплін, забезпечуючи діяльнісну універсальність в опануванні студентами професійних компетентностей.

Серед фахово орієнтованих дисциплін електромеханічних спеціальностей технічні дисцииліни відіграють провідну роль в інтеграційних процесах, спрямованих на досягнення ідейної єдності та діяльнісної універсальності. До таких дисциплін перш за все належать ті, що забезпечують формування професійних компетентностей [18] у майбутніх електромеханіків та інженерів-педагогів електромеханічного профілю (табл. 1). 
Перелік технічних дисциплін, вивчення яких передбачено навчальними планами

Таблиця 1 напрямів підготовки 6.050702 «Електромеханіка», 6.010104.29 «Професійна освіта. Електромеханіка»

\begin{tabular}{|c|l|}
\hline № & \multicolumn{1}{|c|}{ Назва навчального предмету (дисципліни) } \\
\hline 1 & Автоматизований електропривод типових промислових механізмів \\
\hline 2 & Електричні машини \\
\hline 3 & Електроматеріалознавство \\
\hline 4 & Електроніка і мікросхемотехніка \\
\hline 5 & Елементи автоматизованого електроприводу \\
\hline 6 & Метрологія, стандартизація та технічні вимірювання \\
\hline 7 & Механіка та динаміка електромеханічних систем \\
\hline 8 & Мікропроцесорні пристрої \\
\hline 9 & Робототехнічні системи та комплекси \\
\hline 10 & Теоретичні основи електротехніки \\
\hline 11 & Теорія автоматичного управління \\
\hline 12 & Теорія електроприводу \\
\hline
\end{tabular}

Як випливає 3 наведеного переліку дисциплін і змісту їх типових (робочих) навчальних програм, вони мають суттєві відмінності, зокрема у предметних цілях, загальних завданнях, вимогах до результатів навчання, змістових модулях тощо. Оскільки зміст кожної 3 цих дисциплін суттєво відрізняється від змісту інших, то єдиним шляхом ïx інтеграції $є$ досягнення діяльнісної універсальності, що можливо шляхом «упровадження в навчально-виховний процес таких видів навчальних завдань (робіт), які були б діяльнісно близькими і мало залежними від змісту, на якому вони реалізуються, та будувалися в певному розумінні за методично стандартизованим алгоритмом» [20].

Виходячи 3 того, що майбутні фахівці інженери-педагоги електромеханічного профілю - в результаті опанування змістом технічних дисциплін повинні

розуміти:

- значення електромеханічних пристроїв у виробничих процесах;

- принципи

електромеханічних пристроїв;

- принципи

функціонування

електромеханічними пристроями тощо;

знати:

- устрій електромеханічних пристроїв i особливості їх роботи;

- електромеханічні властивості двигунів постійного та змінного струму;

- правила експлуатації та обслуговування електромеханічних пристроїв;
- основи технології

ремонту електромеханічних пристроїв;

- основні положення безпечної роботи електромеханічних пристроїв тощо;

вміти:

- аналізувати різні параметри окремих електромеханічних пристроїв;

- діагностувати режими роботи електромеханічних пристроїв;

- здійснювати аналіз і синтез усталених та перехідних режимів в електромеханічних системах; пристроїв;

- керувати роботою електромеханічних

- здійснювати логічну i математичну обробку показників приладів і сигналів, що надходять $з$ контрольної апаратури тощо,

a, отже, набувати компетенцій, необхідних для практичного розв'язання завдань електромеханічного характеру, інтегруючою основою має стати навчальна експериментальнодослідницька діяльність у процесі опанування змістом технічних дисциплін.

Знання, уміння й навички, якими опановують студенти при опрацьовуванні змісту різних дисциплін, а також досвід експериментування, об'єднуються в компетентнісний комплекс, достатній забезпечити проведення експериментальних досліджень і сформувати в них необхідний практичний досвід і професійні якості, потрібні для діяльності в умовах реального виробничого або навчального процесу. 
Як слушно зауважує методист-математик С. О. Скворцова, «структура базових компетентностей ... складається 3 професійнодіяльнісного, комунікативного й особистісного компонентів» [10, с. 5].

Залежно від характеру педагогічної діяльності ці компоненти набувають певного змістового наповнення у невід'ємному зв'язку 3 діяльнісною спеціалізацією майбутнього фахівця. Так, для інженерів електромеханічного профілю iз професійно-діяльнісного компонента можна виокремити такі базові професійні компетентності:

- предметно-теоретичну, що характеризує наявність цілісної, несуперечливої й практично затребуваної сукупності (системи) наукових знань із фахових дисциплін та готовність i спроможність їх застосувати у професійній діяльності;

- інформаиійно-дослідницьку, що передбачає опанування умінь відшукувати інформацію, систематизувати й узагальнювати іiі здійснювати експериментальні дослідження та готовність удосконалювати власну професійну діяльність через опрацювання і впровадження нової інформації;

- результативно-інтерпретаційну, що характеризує здатність фахівця електромеханічного профілю до інтерпретаційних дій і висновків, набйльш відповідних результатам і змісту експерименту;

- методичну, що забезпечується наявністю «методичних знань та умінь щодо окремих розділів та тем курсу, окремих етапів навчання, готовність проводити заняття за різними навчальними комплектами, володіння педагогічними технологіями» [10, с. 5].

Iз комунікативного компонента услід за С. О. Скворцовою доцільно виділяти такі компетентності:

- комунікативну, що передбачає опанування сукупності вербальних і невербальних засобів професійного спілкування та спроможність до автентичного розуміння й передавання смислу фахової і соціокультурної інформації;

- соиіокультурну, що передбачає спроможність усвідомлювати цінності професійного й освітнього середовища, сучасні соціальні приорітети, закономірності суспільного розвитку, значимість інженерної (та інженернопедагогічної) діяльності у процесах економічної й освітньої розбудови держави;

3 особистісного компонента базових компетентностей майбутнього інженера-педагога електромеханічного профілю мають бути виокремлені такі компетентності:

- рефлексивну, що характеризує спрямованість особистості на досягнення довершеності у професійної діяльності й вироблення адекватної самооцінки власних професійних можливостей і здобутків;

- творчу, що характеризує здатність та прагнення особистості до пошуку оригінальних варіантів розв'язання професійних завдань, проектування компонентів тощо.

На думку О. Е. Коваленко фахова компетентність грунтується на таких компонентах:

- соціальному, що проявляється у загальноправовій свідомості фахівця, його здатності орієнтуватися на ринку праці, у професіях певного напрямку та змісті їх діяльності);

- технічному, що забезпечується не тільки наявністю глибоких технічних знань, але i здатністю до творчого вирішення технічних задач, попередньої обробки й трансляції технічної інформації в педагогічні системи);

- дидактичному, що характеризується поглибленням і систематизацією інженернотехнічних і психолого-педагогічних знань та вмінь, їх інтеграцією в педагогічні структури, на яких базується навчальний процес [7, с. 112114]);

- психологічному, що забезпечується здатністю до відбору й структуруванню науковотехнічної інформації, діагностування досяжних результатів та прогнозування усіляких ускладнень у навчанні, співставлення й відбору оптимальних рішень за заданими критеріями [9, с. 41-42].

Дидактичні позиції С. О. Скворцової та О. Е. Коваленко можуть здаватися на перший погляд різними, якщо брати до уваги лише їхній компонентний склад. Але ж коли загалом деталізувати їх змістове наповнення у професійно-діяльнісному ракурсі, то виявиться що обидві компетентнісні структури семантично еквівалентні. Це означає, що незалежно від вихідних позицій дослідників, компетентність фахівця електромеханічного профілю (хоч електромеханіка, хоч інженера-педагога електромеханічного профілю) передбачає здатність до організації $i$ проведення експериментальних досліджень, оскільки такі дослідження виявляються невід'ємною частиною майбутньої професійної діяльності.

В деяких педагогічних роботах також зустрічається точка зору, згідно 3 якою професійна компетентність викладача (зокрема, й інженерних дисциплін) мислиться як синкретичне утворення, в основі якого лежить сукупність структурантів: педагогічного (що продукується предметним, дидактичним, методичним компонентами), психологокомунікативного, управлінського, проективного, рефлексивного. 
Предметний складник педагогічної компетентності зазвичай витлумачується як теоретична і практична готовність до викладання дисципліни й характеризує здатність фахівця «відшукувати інформацію, аналізувати, узагальнювати і використовувати іiі для навчання; подавати навчальний матеріал у достатньому обсязі обгрунтовано, послідовно», не порушуючи його семантичні характеристики.

Дидактичний складник педагогічної компетентністі вважається тим мірилом, що характеризує спроможність викладача «визначати цілі навчального заняття й всього курсу дисципліни; ... відбирати зміст і відповідне обладнання для проведення навчального заняття; викладати навчальний матеріал доступно, чітко, виразно, переконливо; розробляти дидактичний матеріал для навчального заняття», здійснювати дидактичне проектування.

Методичний складник педагогічної компетентністі фахівця як правило пов'язується із «поінформованістю 3 проблем інновацій в галузі освіти, використанні різноманітних освітніх технологій і засобів навчання, способах організації роботи студентів на занятті» [21, с. 7], а також беззаперечному знанні методичних концепцій побудови навчальної дисципліни та їх практичної реалізації у навчальних курсах i технологіях викладання.

Педагогічний структурант, на якому базується професійна компетентність викладача відіграє роль об'єктивного фундаменту, на якому формуються суб'єктивні якості (у тому числі й компететнісні) фахівця та досвід його педагогічної діяльності. Серед найбільш значущих компетентностей такого плану слід відзначити наступні.

Психолого-комунікативна компетентність характеризує здатність фахівця «стимулювати пізнавальні інтереси студентів на заняттях; здійснювати мотивацію кожного навчального заняття; формувати позитивне ставлення студентів до навчання; актуалізувати знання i життєвий досвід студентів; адекватно сприймати та розуміти студентів; створювати позитивний психологічний клімат на занятті».

Управлінська компетентність фахівця являє собою здатність «планувати, організовувати й контролювати навчальновиховний процес та власну професійну діяльність для досягнення прогнозованого результату» $\mathrm{i}$ передбачає наявність уміння конкретизувати предметні, розвивальні і виховні цілі навчання; діагностувати й «оцінювати рівень навчальних досягнень учнів; використовувати різні види i методи контролю; керувати роботою студентів на заняттях; організовувати самостійну роботу студентів; визначати педагогічні задачі відповідно до предмету» [21, с. 7], розробляти програми індивідуального розвитку учнів (слухачів).

Проективна компетентність фахівця може витлумачуватися як спроможність передбачати наслідки фахової діяльності, результати навчально-виховної діяльності; здатність «розробляти навчальні плани і програми 3 дисципліни; ... плани занять; проектувати навчальний процес та діяльність студентів на занятті; проектувати і прогнозувати власну педагогічну діяльність відповідно до предмету» $[21$, c. 8$]$.

Рефлексивна компетентність фахівця зазвичай мислиться як здатність фахівця аналізувати результати власної діяльності та спрямовувати власні знання на іiі удосконалення тощо.

Безсумнівно, можна й далі аналізувати точки зору різних авторів, але за будь яких умов i відмінностей залишається актуальним тлумачення професійної компетентності особистості, запропоноване А. А. Бодальовим, В.І. Жуковим, Л.Г. Лаптевим, В.О. Слатьоніним:

Професійна компетентність особистості $\epsilon$ складним системним утворенням, основними елементами якого є декілька підсистем:

- «професійних знань як логічної системної інформації про навколишній i внутрішній світ людини, зафіксованої в іiі свідомості;

- професійних умінь як психічних утворень, що полягають у засвоєнні людиною способів і технік професійної діяльності;

- професійних навичок - дій, сформованих в процесі повторення певних операцій і доведених до автоматизму;

- професійних позицій як сукупності сформованих установок і орієнтацій, відношення та оцінок внутрішнього і навколишнього досвіду, реальності і перспектив, а також домагань, які визначають характер професійної діяльності і поведінки фахівця;

- індивідуально-психологічних

особливостей фахівця - поєднання різних структурно-функціональних компонентів психіки, які визначають індивідуальність, стиль професійної діяльності, поведінки і виявляються у професійних якостях особистості;

- акмеологічних інваріантів - внутрішніх збудників, які обумовлюють потребу фахівця в постійному саморозвитку, творчості та самовдосконаленні» [16, с. 334-335].

Комплекс цих підсистем у процесі фахового становлення особистості майбутнього інженерапедагога електромеханічного профілю орієнтує його не тільки на опанування професійно важливими компетенціями, а й на усвідомлення специфіки i особливостей майбутньої професійної діяльності. 
При цьому, як слушно зазначає В. А. Петрук, «майбутній інженер може усвідомити специфіку обраної професійної діяльності тільки в процесі виконання конкретних професійних дій, що зумовлює необхідність орієнтації його професійної підготовки на модель виробництва, основу якої становлять принципи співпраці та взаємодії в досягненні запланованих цілей, спільні дії в систематичному підвищенні економічних результатів праці, уміле проектування й реалізація конкретних заходів щодо організації й управління виробничим» [15, с. 93], експериментальним, інформаційним, дослідницьким, навчально-виховним чи якимсь іншим процесом.

У цьому контексті та за умов інформаційного розвитку соціуму виключно важливого значення набуває й ще один компонент професійної зрілості фахівця інформаційно-дослідницький. Цей компонент грунтується на інформаційному підході, сутність якого схарактеризована В. В. Стешенком [19].

Як зазначає В. В. Стешенко, «інформаційний ... підхід дозволяє вивчати взаємовідношення та взаємозв'язки для конкретних об'єктів (процесів чи явищ).

Сутність ... [його] полягає в тому, що основна увага переноситься 3 елементів окремо взятої системи на мікро- та макромірні на, так названі, кодовосотові відношення та зв'язки, які існують не тільки в даній системі, а й 3 оточуючими системами. Іншими словами, це відношення та зв'язки між певними елементами інформації про певні об'єкти дійсності, яка розміщена в певних місцях оточуючого середовища (сотах) та має свій певний код» [19, с. 39].

Цілком слушно зазначається, що «характерними особливостями інформаційного підходу є:

- передбачення початкового проведення аналізу та синтезу відношень всередині предметів i їх елементів та їх відношень 3 оточуючим середовищем;

- вихід 3 об'єктивності відношень (інформації);

- розгляд реальних речей, предметів та об'єктів як похідних цих відношень» [там само, с. 39].

«Інформаційним вважається такий процес, який виникає в результаті відношень та взаємодії елементарних складових - носіїв інформації. Визначена і одиниця елементарного відношення, яка називається інформаціоном. Вона $\epsilon$ генералізаційним носієм відношень. Інформаціон може мати свою назву, класифікацію, властивості, ознаки, явища тощо. В педагогічній системі, зокрема, в системі знань в якості інформаціонів виступають міжпредметні зв'язки, які $\epsilon$ такими відношеннями між навчальними дисциплінами ...

Перехід до інформаційного [підходу] дозволяє піднятися на більш високий рівень наукових досліджень. Його використання в педагогічних дослідженнях надає нові можливості для вивчення навчального та виховного процесів, процесів формування особистісних якостей школярів і студентів, що може привести до нових результатів » [там само, с. 40].

В контексті побудови змісту навчальних дисциплін інформаційний підхід має значні перспективи. «Наприклад, вивчення дидактичних зв'язків як інформаційних відношень у системі змісту освітньої чи освітньо-професійної підготовки школярів, чи студентської молоді дозволить розробити педагогічно ефективну систему змісту навчального процесу» [там само, с. 40], зорієнтовану на опанування професійними компетентностями в межах програм підготовки фахівців, в тому числі й інженерів-педагогів електромеханічного профілю.

Якщо мислити інформаційний компонент у поєднанні $з$ дослідницьким напрямом діяльності майбутнього інженера-педагога, то можна говорити про інформаиійно-дослідницький компонент у структурі підготовки майбутніх фахівців.

Інформаційно-дослідницький компонент професійної компетенції фахівців електромеханічного профілю, що грунтується на здатності до проведення експериментальних досліджень та готовності до вдосконалення власної професійної діяльності, з урахуванням інтеграційного підходу до методичного забезпечення навчання технічним дисциплінам шляхом досягнення діяльнісної універсальності при опануванні їх змістом, $\epsilon$ основою для позиціонування експериментальних досліджень як основи формування професійної компетентності інженерів-педагогів електромеханічного профілю.

Зважаючи на те, що компетентність - це «інтегрована характеристика якостей особистості, результат підготовки випускника вузу для виконання діяльності в певних професійних та соціально-особистістних предметних областях (компетенціях), який визначається необхідним обсягом і рівнем знань та досвіду у певному виді діяльності» [13, с. 46], слід зазначити що в проекції на експериментально-дослідницьку діяльність інженерів-педагогів електромеханічного профілю вона має грунтуватися (окрім соціально-особистісних, загальнонаукових й інструментальних 
компетенцій) на загально-професійних та спеціалізовано-професійних компетенціях.

Зокрема, серед загально-професійних компетенцій, які відіграють суттєве значення в експериментально-дослідницькій діяльності відзначаються ті, що спрямовуються на:

- формування базових уявлень про електромеханічні пристрої (об’єкти), їх різноманітність, розуміння їхнього призначення i принципів роботи;

- опанування методами спостереження, опису, ідентифікації, виявлення особливостей функціонування електромеханічних пристроїв (об'єктів);

- забезпечення дій i режимів роботи електромеханічних пристроїв (об'єктів).

Серед спеціалізовано-професійних компетенцій, необхідних для експериментальнодослідницької діяльності інженерів-педагогів електромеханічного профілю виділяються здатності:

- аналізувати, планувати й організовувати експериментальні дослідження електромеханічних пристроїв (об'єктів);

- застосовувати загальні, технологічні, аналітичні i спеціальні методи експериментальних досліджень для визначення статистичних i динамічних характеристик, режимів функціонування електромеханічних пристроїв (об'єктів);

- використовувати професійно профільовані знання в галузі електромеханіки для статистичної обробки експериментальних даних і математичного моделювання електромеханічних явищ і процесів;

- $\quad$ застосовувати математичний апарат в інженерному експериментуванні.

Комплекс охарактеризованих складників фахової компетентності визначає загальні напрями, за якими має відбуватися формування відповідних здатностей та досвіду експериментальної діяльності у студентів при опануванні змістом технічних дисциплін.

Якщо узяти за основу їх перелік, наведений у табл. 2, та проаналізувати зміст відповідних навчальних програм, то можна виділити для кожної 3 дисциплін коло питань, практична спрямованість яких забезпечується при залученні майбутніх фахівців до експериментальних досліджень методів, засобів і характеристик предмета вивчення: автоматизованого електроприводу (що конкретизовано А. В. Башаріним та Ю. В. Постніковим $[1 ; 2])$, електричних машин (О. Д. Гольдберг [4]), електроматеріалів (В. Г. Герасимовим [22]) та ін.

Групуючи їх за предметним принципом, отримаємо комплекс базових питань, експериментальне дослідження яких дозволяє майбутнім фахівцям набувати досвіду практичного застосування теоретичних знань (табл. 2), а також формувати професійний світогляд і навички практичних дій.

Зміст експериментальних досліджень у фахових дисциплінах електромеханічного спрямування.

\begin{tabular}{|c|c|c|}
\hline № & Назва предмету (дисципліни) & Зміст експериментальних досліджень \\
\hline 1 & $\begin{array}{l}\text { Автоматизований електропривод } \\
\text { типових промислових механізмів }\end{array}$ & $\begin{array}{l}\text { Методи, засоби і характеристики автоматизації } \\
\text { електроприводу типових промислових механізмів }\end{array}$ \\
\hline 2 & Електричні машини & $\begin{array}{c}\text { Характеристики електричних машин. } \\
\text { Методи і засоби випробування електричних } \\
\text { машин. }\end{array}$ \\
\hline 3 & Електроматеріалознавство & $\begin{array}{c}\text { Методи, засоби і особливості дослідження } \\
\text { властивостей та характеристик електроматеріалів }\end{array}$ \\
\hline 4 & Електроніка і мікросхемотехніка & $\begin{array}{c}\text { Методи, засоби і особливості дослідження } \\
\text { властивостей та характеристик елементної бази } \\
\text { електроніки та мікросхемотехніки }\end{array}$ \\
\hline 5 & $\begin{array}{c}\text { Елементи автоматизованого } \\
\text { електроприводу }\end{array}$ & $\begin{array}{c}\text { Методи та засоби дослідження систем } \\
\text { автоматизації електроприводу }\end{array}$ \\
\hline 6 & $\begin{array}{c}\text { Метрологія, стандартизація та технічні } \\
\text { вимірювання }\end{array}$ & $\begin{array}{c}\text { Поняття інженерного експерименту; методи } \\
\text { оцінювання хибок при вимірюваннях; методи та } \\
\text { засоби вимірювання електричних і } \\
\text { неелектричних величин; застосування } \\
\text { обчислювальної техніки при вимірюваннях }\end{array}$ \\
\hline
\end{tabular}




\begin{tabular}{|c|c|c|}
\hline № & Назва предмету (дисципліни) & Зміст експериментальних досліджень \\
\hline 7 & $\begin{array}{c}\text { Механіка та динаміка } \\
\text { електромеханічних систем }\end{array}$ & $\begin{array}{c}\text { Методи та засоби дослідження динамічних } \\
\text { характеристик електромеханічних систем }\end{array}$ \\
\hline 8 & Мікропроцесорні пристрої & $\begin{array}{c}\text { Методи та засоби дослідження функціональних } \\
\text { характеристик мікропроцесорних пристроїв }\end{array}$ \\
\hline 9 & Робототехнічні системи та комплекси & $\begin{array}{c}\text { Методи та засоби дослідження функціональних } \\
\text { характеристик робототехнічних систем }\end{array}$ \\
\hline 10 & Теоретичні основи електротехніки & $\begin{array}{c}\text { Дослідження робочих властивостей і } \\
\text { характеристик електротехнічних пристроїв }\end{array}$ \\
\hline 12 & Теорія автоматичного управління & $\begin{array}{c}\text { Методи, засоби та особливості дослідження } \\
\text { систем автоматичного управління }\end{array}$ \\
\hline \multirow{2}{*}{12} & Теорія електроприводу & $\begin{array}{c}\text { Методика інженерного експерименту: принципи } \\
\text { постановки задачі, методи аналізу, планування і } \\
\text { організації експерименту; дослідження силової } \\
\text { частини електроприводу, його статистичних і } \\
\text { динамічних характеристик }\end{array}$ \\
\hline
\end{tabular}

Природно, окрім фахово зорієнтованих технічних дисциплін в системі підготовки електромеханіків $\epsilon$ кілька фундаментальних (інформатика, фізика, математика (математична статистика)), які забезпечують експериментальні дослідження універсальним інструментарієм, що дозволяє здійснювати:

- відбір, обробку та накопичення інформації iз застосуванням комп'ютерних засобів, включаючи належне програмне забезпечення [11];

- використання методів, що застосовувалися при проведенні фізичних експериментів [6];

- статистичну обробку експериментальних даних [14], оцінювання та перевірку гіпотез, перевірку критеріїв згоди та ін.

В. А. Петрук, досліджуючи концептуальні підходи до розробки змісту й організації процесу формування професійної спрямованості, вмінь самостійної роботи у студентів, зазначає: «для того, щоб сформувати компетентність спеціаліста, студенту потрібно здійснити діяльність, адекватну тій, яка втілена в продуктах соціального досвіду: знаннях, навичках, засобах і знаряддях конкретної професійної діяльності. В навчанні ці продукти за необхідністю мають знакову форму - форму навчальної інформації і виступають змістом навчання» [15, с. 99]. Продукти соціального досвіду, втілені у знаряддях інженерної, а також інженернопедагогічної діяльності, потребують від фахівців відповідного рівня кваліфікації для застосування ï $\mathrm{y}$ виробничих чи педагогічних процесах $[17$, c. 96]. Досвід такого застосування формується в системі підготовки майбутніх інженерів-педагогів електромеханічного профілю при проведенні експериментальних досліджень, а також в інженерному експерименті як складовій процесу опанування змістом технічних дисциплін.

Керованість цією системою забезпечується завдяки управлінському впливу на наступні компоненти: цілепокладання діяльності, когнітивні метафори моделі [12] навчальнопрофесійної діяльності; систему підготовки майбутніх фахівців до проведення інженерного експерименту як джерело результату, i педагогічні умови - як зовнішні чинники, що регулюють перебіг процесу. В загальному вигляді підготовка майбутніх інженерів-педагогів електромеханічного профілю до проведення експериментальних досліджень має такий вид: 


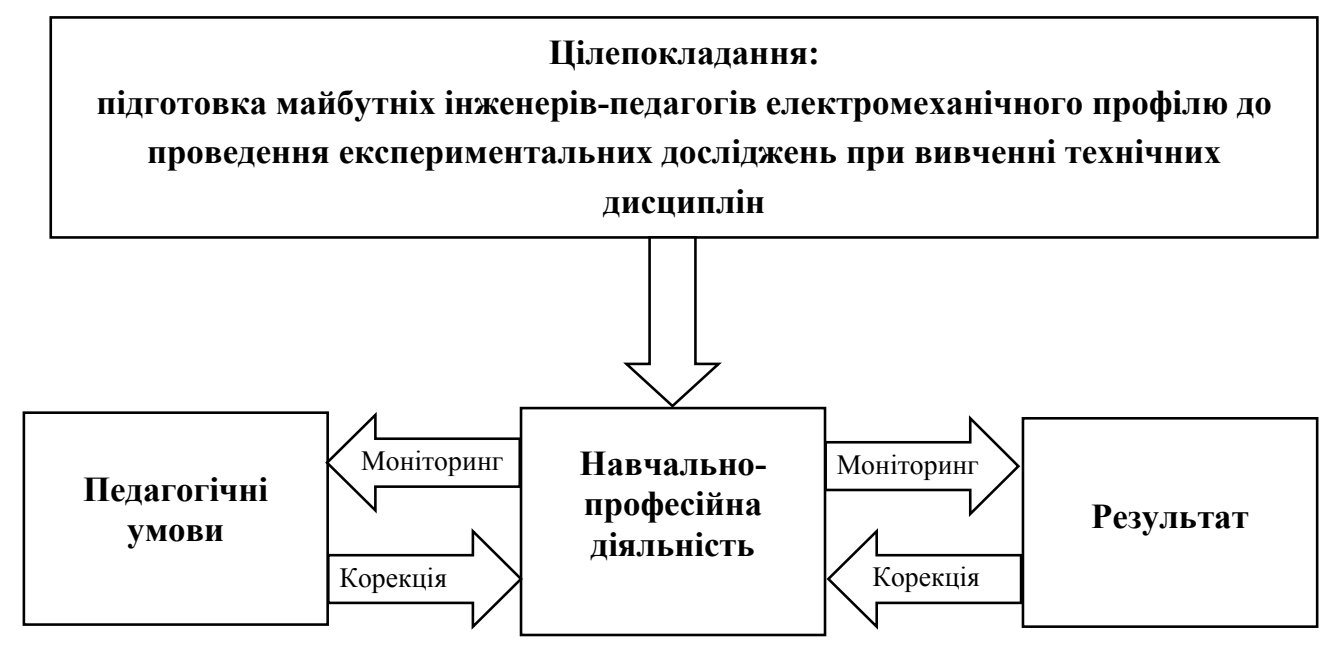

\section{Рис. 1 - Реалізація цілепокладання в підготовці майбутніх інженерів-педагогів електромеханічного профілю.}

Звертаючись до цієї схеми, зауважимо, що у навчальному процесі, складовою якого $\epsilon$ підготовка майбутніх інженерно-педагогічних фахівців електромеханічного профілю до експериментальної діяльності, педагогічні умови визначають зовнішні обставини, в яких відбувається навчально-професійна діяльність, і розглядаються як чинники, що сприяють або перешкоджають їй.

Отже, на процес підготовки майбутніх інженерів-педагогів електромеханічного профілю до проведення експериментальних досліджень може здійснюватися управлінський вплив через зміну педагогічних умов [8], або ж корегування характеристик і параметрів навчальнопрофесійної діяльності, що супроводжує опанування майбутніми фахівцями змістом технічних дисциплін.

Висновки. На підставі аналізу методологічних, психолого-педагогічних, фахових, інженерно-педагогічних джерел, навчальної і методичної літератури попередніх i останніх років, встановлено, що експериментальні дослідження при вивчення фахово орієнтованих (технічних) дисциплін електромеханічних спеціальностей мають потенціал для реалізації провідної ролі в інтеграційних процесах, спрямованих на досягнення ідейної єдності та діяльнісної універсальності при опрацьовуванні змісту фахово орієнтованих технічних дисциплін, формування у майбутніх фахівців компетентнісного комплексу, достатнього для професійної діяльності в умовах реального виробничого або навчального процесу.

Аналіз практики підготовки майбутніх фахівців до експериментальних досліджень при вивченні технічних дисциплін в контексті соціокультурних умов розвитку суспільства, зв'язків експериментальної діяльності 3 компетентнісним розвитком інженерів-педагогів електромеханічного профілю дає підстави констатувати, що досліджувана проблема має важливе практичне значення, оскільки $\epsilon$ невід'ємною частиною фахової підготовки, яка має забезпечувати не тільки належний рівень теоретичних знань, а й достатній досвід експериментальної діяльності в інженерній сфері - тій сфері, для професійного життя в якій готується фахівець.

\section{References:}

1. Basharyn AV (1990) Prymery rascheta avtomatyzyrovannogo elektropryvoda na EVM: [ucheb. posob. dlja vuzov po spec. «Elektropryvod y avtomatyzacyja promyshlennyh ustanovok y tehnologycheskyh kompleksov» / Artemyj Vasyl'evych Basharyn, Juryj Vladymyrovych Postnykov. - 3-e yzd., pererab . - L. : Energoatomyzdat, -512.
2. Basharyn AV (1971) Prymery raschetov avtomatyzyrovannogo elektropryvoda / Artemyj Vasyl'evych Basharyn, Feodosyj Nykolaevych Golubev, Vasylyj Georgyevych Kepperman. - L. : Energyja, - 440.

3. Bjelova JJ (2012) Zadachi integracii' tehnichnyh dyscyplin u profesijnij pidgotovci majbutnih inzheneriv-pedagogiv / Julija 
Jurii'vna Bjelova // Modernyzacyja nauchnyh yssledovanyj : HHI Mezhdunar. nauch.-prakt. konferencija po filosof., filolog., jurydych., pedagogych., jekonomych., psyhologych., socyologych. y polytych. naukam (Ukrayna, g. Gorlovka, 17-18 maja 2012.). - Gorlovka : Pantjuh Ju. F., 2012. - pp. 171-172.

4. Gol'dberg OD (1990) Yspytanyja elektrycheskyh mashyn / Oskar Davydovych Gol'dberg. - Moscow: Vysshaja shkola, - 255.

5. Goncharenko SU (1994) Integracija naukovyh znan' i problema zmistu osvity / Semen Ustymovych Goncharenko // Postmetodyka. № 2. - pp. 2-3.

6. Grebenev YV, Chuprunov EV (2009) Modelyrovanye kak funkcyja teoryy obuchenyja predmetu: Ygor' Vasyl'evych Grebenev, Evgenyj Vladymyrovych Chuprunov // Pedagogichna nauka: istorija, teorija, praktyka, tendencii' rozvytku. - Vыр. № 4 [2009]. Available: http://intellectinvest.org.ua/ukr/pedagog_editions e magazine pedagogical science arhiv pn n4 2 009 st $10 /$

7. Gura OI (2006) Psyhologo-pedagogichna kompetentnist' vykladacha vyshhogo navchal'nogo zakladu. Teoretykometodologichnyj aspekt : monografija / Oleksandr Ivanovych Gura. - Zaporizhzhja : GU «ZIDMU», - 332 .

8. Gura SO (2004) Organizacijno-pedagogichni umovy adaptacii' majbutnih inzhenerivpedagogiv : avtoref. dys. ... kand. ped. nauk : 13.00.04 [spec. "Teorija i metodyka profesijnoi' osvity»] / Svitlana Oleksandrivna Gura ; Hark. derzh. ped. un-t im. G.S. Skovorody. - H., pp. 20.

9. Kovalenko OE (2003) Metodyka professyonal'nogo obuchenyja: ucheb. dlja ynzhenerov-pedagogov, prepodavatelej specdyscyplyn systemy professyonal'notehnycheskogo y vysshego obrazovanyja / Olena Eduardovna Kovalenko. - H. : Shtryh, 480.

10. (2010) Kompetentnisno zorijentovana programa kursu «Metodyka navchannja matematyky v pochatkovij shkoli» : dlja naprjamu pidgotovky 0101 «Pedagogichna osvita» : osvitn'okvalifikacijnyj riven' - bakalavr / S. O. Skvorcova [ukl.]. - Odesa : PNPU im. K.D.Ushyns'kogo, 2010. - 100 s. // Skvorcova Svitlana Oleksii'vna: - Available: http://skvor.info/students/metodika/info.html

11. Kuleshova EO (2011) Teoretycheskye osnovы эlektrotehnyky v эksperymentah y uprazhnenyjah. Praktykum v srede Electronics Workbench : uchebnoe posobye / Elena Olegovna Kuleshova, Veronyka Andreevna Kolchanova, Vladyslav Dmytryevych Es'kov,
Serge Vladymyrovych Pustynnykov; Nacyonal'nyj yssledovatel'skyj Tomskyj polytehnycheskyj unyversytet. - Tomsk. - 148.

12. Lodatko JO (2013) Klasteryzacija sociokul'turnogo prostoru i kognityvni metafory $\mathrm{v}$ pedagogichnomu modeljuvanni / Jevgen Oleksandrovych Lodatko. Pedagogika vyshhoi' shkoly : metodologija, teorija, tehnologii' // Visnyk Cherkas'kogo universytetu. Serija : Pedagogichni nauky. - Vyp. 6(259). 2013. Cherkasy : ChNU im. Bogdana Hmel'nyc'kogo, 2013. - pp. 53-58.

13. Marushhak JJ (2005) Syntez elektromehanichnyh system $\mathrm{z}$ poslidovnym ta paralel'nym koryguvannjam. Jaroslav Jurijovych Marushhak. - L'viv: LP, - 208.

14. Pavlenko LV (2012) Doslidnoeksperymental'na perevirka rozroblenoi' metodyky navchannja majbutnih inzhenerivpedagogiv komp'juternyh tehnologij statystychnogo opracjuvannja eksperymental'nyh danyh / Lilija Vasylivna Pavlenko // Novitni komp'juterni tehnologii' NOCOTE'2012 : materialy 10-toi' juvilejnoi' Mizhnarodnoi' naukovo-tehnichnoi' konferencii'. - Sevastopol' : Prynt, 2012. - pp. 91-92.

15. Petruk VA (2006) Teoretyko-metodychni zasady formuvannja profesijnoi' kompetentnosti majbutnih fahivciv tehnichnyh special'nostej u procesi vyvchennja fundamental'nyh dyscyplin : monografija / Vira Andrii'vna Petruk. Vinnycja: UNIVERSUM-Vinnycja, 2006. 292.

16. (2002) Psyhologyja y pedagogyka : ucheb. posob. / Pod red. A. A. Bodaleva, V. Y. Zhukova, L. G. Lapteva, V. A. Slastenyna. Moscow: Yzd-vo Ynstytuta Psyhoterapyy, 2002. -585 .

17. Serdjukova OJ (2010) Osnovy inzhenernopedagogichnoi' dijal'nosti (Vstup do fahu) : kurs lekcij $\mathrm{Z}$ dyscypliny dlja stud. I kursu spec. «Prof. navchannja» / Olena Jakivna Serdjukova ; Derzh. zakl. «Lugan. nac. un-t im. Tarasa Shevchenka». - Lugans'k : LNU im. Tarasa Shevchenka, -143.

18. Sydorenko V (2010) Suchasni harakterystyky profesijnoi' kompetentnosti / Viktor Sydorenko // Trudova pidgotovka $\mathrm{v}$ zakladah osvity : nauk.-metod. zhurn. - 2010. - № 5. - pp. 3-7.

19. Steshenko VV (2004) Teoretykometodologichni zasady fahovoi' pidgotovky majbutn'ogo vchytelja tehnologii' v umovah stupenevoi' osvity : monografija / Volodymyr Vasyl'ovych Steshenko. - Slov'jans'k : SDPU, 2004. - 188.

20. Torubara OM (2007) Analiz vymog (pryncypiv) pobudovy struktury navchal'nogo materialu / Oleksij Mykolajovych Torubara // 
Ynnovacyonnye obrazovatel'nye tehnologyy. 2007. - № 4(12) - pp. 46-50.

21. Hodarchenko OG (2012) Zmist profesijnoi' kompetentnosti vykladacha VNZ I-II rivniv akredytacii', sutnist' ta mehanizm i'i' monitoryngu / O. G. Hodarchenko // Students'kyj al'manah : zb. magisters'kyh robit. - 2012. - № 1. - 11. - Available: http://mp2.umo.edu.ua/wpcontent/uploads/Hodarchenko.pdf

22. (2003) Elektrotehnycheskyj spravochnyk: V 4-h t. - T. 1. Obshhye voprosy. Elektrycheskye materyaly / Pod red. V. G. Gerasymova [y dr.]. - 9-e yzd., yspr. y dop. - Moscow: MEY, 2003. -440 . 